\title{
Relationship of Obesity with Vital Lung Capacity
}

\author{
(Medical Faculty Student of Jenderal Achmad Yani University)
}

\author{
Apen Afgani* \\ Department of Internal Medicine \\ Jenderal Achmad Yani University \\ Cimahi, Indonesia \\ *apen.afgani@fk.unjani.ac.id

\section{Priatna} \\ Department of Radiology \\ Jenderal Achmad Yani University \\ Cimahi, Indonesia
}

\author{
Ali Yasin \\ Faculty of Medicine \\ Jenderal Achmad Yani University \\ Cimahi, Indonesia
}

\author{
Muhammad Adam Zulqarnain \\ Faculty of Medicine \\ Jenderal Achmad Yani University \\ Cimahi, Indonesia \\ adam.zulqarnain77@gmail.com
}

\begin{abstract}
Obesity is a disorder or disease that is characterized by abnormal accumulation of fat or excessive in adipose tissue which can interfere their health. In people with obesity, there are fat deposits in the thoracic cavity and stomach decrease of causing process respiratory disorder, therefore it tends to occur on obesity pulmonary capacity which would result in a decrease in lung function. The purpose of this research was to know the relationship of obesity with vital lung capacity. The subject of research was the obese Medical Faculty student of Jenderal Achmad Yani University from batch 2015 until batch 2018. The sample was obtained by as many as 31 people whom obtained using simple random sampling. This research method used correlative analytic observational study with cross-sectional. Data analysis using SPSS program to test the Spearman Correlation Test. Results of the research showed a relationship between Lung vital capacity with obesity in students of the Faculty of Medicine of the University of Jenderal Achmad Yani ( $\mathbf{p}<\mathbf{0 . 0 5}$ ). The higher body mass index values cause vital lung capacity decreased.
\end{abstract}

\section{Keywords—obesity, lung vital capacity}

\section{INTRODUCTION}

Obesity and being overweight (overweight) are the accumulation of excess or abnormal fat that can cause health problems. In 2008 about 1.5 billion adults were overweight (overweight), and among them two hundred million men and nearly three hundred million women were obese. Globally 2.8 million people died from obesity or overweight (overweight) and 300,000 of them in Southeast Asia [1]

Based on the 2013 Basic Health Research in Indonesia, the rate of overweight and obesity at over 18 years of age was recorded at $27.1 \%$. The prevalence of the thin adult population was $8.7 \%$, overweight was $13.5 \%$, and obesity was $15.4 \%$. The prevalence of obese adult male population in 2013 has increased compared to 2007 and 2010, it was recorded that in 2013 there were $19.7 \%$ obese adult men, $13.9 \%$ in 2007 , and $7.8 \%$ in 2010. In 2013, the lowest prevalence was in East Nusa Tenggara at $9.8 \%$ and the highest prevalence was in North Sulawesi at $34.7 \%$. The prevalence of obesity for adult women in 2013 at the age> 18 years was $32.9 \%$, this percentage increased by $18.1 \%$ from 2007 which had a percentage value of $13.9 \%$ and in 2010 there was an increase of $17.5 \%$ with a value percentage $15.5 \%$ [2].

The picture of obesity in West Java in 2015 was around 263,159 people and 23,225 indicated obesities, reporting from 14 districts/cities (52\%), with the largest obesity rate located in Sukabumi City as much as $1.95 \%$, and the lowest obesity rate was located in Bogor District 0.01\% [3].

Obesity is a major risk factor for cardiovascular disease of several types of cancer and type 2 diabetes mellitus. In addition, in several studies it is also known that obesity is associated with various respiratory disorders including airflow resistance, breathing patterns, gas exchange, respiratory mechanics, and finally resulting in abnormalities in pulmonary function tests [4]

In obese patients, there may be changes in the characteristics of the respiratory mechanical system, namely the presence of adipose tissue around the ribs, abdomen, and visceral cavities that fill the chest wall resulting in increased intra-abdominal pressure, decreasing end-expiratory lung volume, decreased chest wall compliance, increased respiratory work. which is basically due to a decrease in expiratory residual volume, vital capacity, and total lung capacity $[5,6]$.

Obesity can also cause respiratory disorders, namely Obstructive Sleep Apnea (OSA) and Obesity Hypoventilation Syndrome (OHS) [7]. To assess lung, function the most commonly used tool is spirometry. Spirometry can be used for 
diagnosis and monitoring of respiratory diseases, preparation for surgery, and research [8].

The results of Jannah et al. stated that medical students have a fairly dense lecture schedule, resulting in students having unbalanced eating habits. In addition, students do not exercise due to their busyness and many things, causing many students to be obese [9].

Previous studies from Pinzon conducted on medical students aged 18-22 years showed that the vital capacity of a person's lungs can be affected by his body mass index. Individuals with the normal-excess body have a lower percentage of vital lung capacity than the normal-thin individuals [10]. The results of a study by Stephanie conducted on students of the Unjani Faculty of Medicine stated that there was a relationship between body weight, height, and body surface area with lung vital capacity [11].

Based on these descriptions, researchers conducted research on the relationship between obesity and vital lung capacity in students of the Faculty of Medicine, University of Jendral Achmad Yani.

\section{METHODS}

This research method used correlative analytic observational study with cross-sectional. The subject of research was the obese Medical Faculty student of Jenderal Achmad Yani University from batch 2015 until batch 2018. The student who smoked or had a smoking history, had a respiratory disease, and had a cardiovascular disease were excluded. The sample was obtained by as many as 31 people whom obtained using simple random sampling. The BMI of sample was counted by measured their weight and height, then vital lung capacity got from maximum expiratory volume after maximum inspiration using spirometry. Data analysis using SPSS program to test the Spearman Correlation Test. Vital lung capacity data normality test using Shapiro Wilk test for a sample size of fewer than 50 people and data is not normally distributed with a p-value of 0.001 .

\section{RESULTS AND DISCUSSION}

This research was conducted at the Physiology Laboratory of the Faculty of Medicine, Jenderal Achmad Yani University. The subjects of this study were 31 obese students consisting of 14 males and 17 females at the Faculty of Medicine, Jenderal Achmad University Yani at the undergraduate stage who has met the inclusion and exclusion criteria.

TABLE I. OVERVIEW OF HEIGHT, WEIGHT, AND BODY MASS INDEX

\begin{tabular}{|l|l|l|l|l|l|l|}
\hline No & \multicolumn{1}{|c|}{ Variable } & Mean & \multicolumn{1}{|c|}{ SD } & Median & Min & Max \\
\hline 1 & Height & 162.03 & 9.996 & 159 & 147 & 179 \\
\hline 2 & Weight & 82.16 & 16.48 & 81 & 58 & 133 \\
\hline 3 & Body Mass Index & 31.08 & 4.75 & 30 & 26 & 42 \\
\hline
\end{tabular}

Table 1 show that the average body weight of the Medical Faculty undergraduate students, Jenderal Achmad Yani
University is $82.16 \mathrm{~kg}$ with a standard deviation of $16.48 \mathrm{~kg}$, a median of $81 \mathrm{~kg}$, with the lowest body weight of $58 \mathrm{~kg}$ and the highest being $133 \mathrm{~kg}$.

Table 1 show that the average height of the Medical Faculty undergraduate students, Jenderal Achmad Yani University, undergraduate stage is $162.03 \mathrm{~cm}$ with a standard deviation of $9.996 \mathrm{~cm}$, the median is $159 \mathrm{~cm}$ with the lowest height of 147 $\mathrm{cm}$ and the highest height of $179 \mathrm{~cm}$.

Based on Table 1, it shows that the average body mass index of Medical Faculty students, Jenderal Achmad Yani University who is obese is $31.08 \mathrm{~kg} / \mathrm{m} 2$ with a standard deviation of 4.75 , median $30 \mathrm{~kg} / \mathrm{m} 2$ with the lowest body mass index of $26 \mathrm{~kg} / \mathrm{m} 2$ and a maximum of $42 \mathrm{~kg} / \mathrm{m} 2$. These results indicate that the average body mass index of students is classified as grade 2 obesities according to Asia Pacific criteria. This situation increases the risk of health problems and can have an impact such as respiratory problems, decreased lung function, increased risk of cardiovascular disease, metabolic syndrome, and joint disorders [3,12-14]. In 37 Junior High School students in South Jakarta, the quality of life for obese adolescents is lower than adolescents who are not obese [10].

TABLE II. CHARACTERISTICS OF THE LUNG VITAL CAPACITY

\begin{tabular}{|l|l|}
\hline \multicolumn{1}{|c|}{ Vital Lung Capacity } & \multicolumn{1}{c|}{ n } \\
\hline Mean (SD) & $3.25(0.887)$ \\
\hline Median & 2.950 \\
\hline Minimum & 2.1 \\
\hline Maximum & 4.8 \\
\hline
\end{tabular}

Table 2 shown that the average pulmonary $\mathrm{CV}$ for undergraduate students who are obese at the Faculty of Medicine, Jenderal Achmad Yani University is 3.25 liters with a standard deviation of 0.887 , median 2.950 with the lowest $\mathrm{KV}$ of 2.1 liters and the highest is 4.8 liters.

Before statistical analysis was carried out, for numerical data the normality test was carried out using Shapiro Wilk because the sample size was $\leq 50$ on the body mass index and vital lung capacity of students of the Faculty of Medicine, Jenderal Achmad Yani University in Table 3.

TABLE III. NORMALITY TEST OF BODY MASS INDEX AND LUNG CV

\begin{tabular}{|l|l|l|}
\hline \multirow{2}{*}{ Variable } & \multicolumn{2}{c|}{ Normality test } \\
\cline { 2 - 3 } & \multicolumn{1}{|c|}{$\boldsymbol{p}$-value } & Data Distribution \\
\hline BMI & 0,001 & Not normal \\
\hline Vital Lung Capacity & 0,001 & Not normal \\
\hline
\end{tabular}

Table 3 show that the normality test with the Shapiro Wilk distribution of BMI data on undergraduate students who are obese at the Faculty of Medicine, Jenderal Achmad Yani University has an abnormal distribution with a p-value of 0.001 ( $p$ < 0.05 ) and the distribution of pulmonary CV data for undergraduate students who are obese at the Faculty of Medicine, Jenderal Achmad Yani University, have an abnormal distribution with a p-value of 0.001 ( $p<0.05)$ 
TABLE IV. CORRELATION OF LUNG BMI AND CV

\begin{tabular}{|c|c|c|}
\hline Correlation & r & p-value \\
\hline BMI $><$ Vital Lung Capacity & $-0,38$ & $0,035^{*}$ \\
\hline
\end{tabular}

Based on Table 4, it can be seen that the results of the Spearman Correlation Test analysis at the $95 \%$ degree of confidence indicate that statistically, there is a correlation between BMI and KV of the Lung in the Faculty of Medicine, Jenderal Achmad Yani University Students at the Undergraduate Stage with a p-value of 0.035 (p-value $\leq 0.05$ ) with a correlation strength of -0.38 which indicates moderate correlation strength.

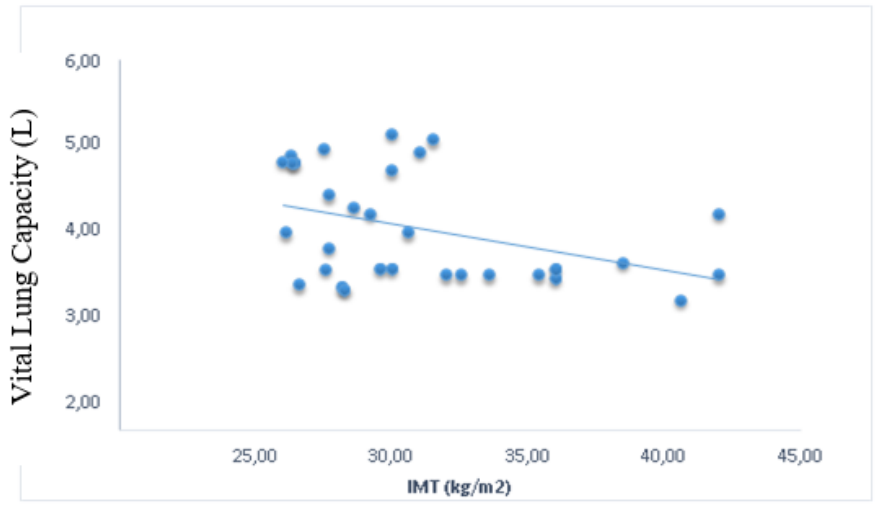

Fig. 1. Graph of lung BMI and CV correlation.

Based on Fig. 1 above, it is found that students who have a lower body mass index have higher lung vital capacity results, and students who have a higher body mass index have lower lung vital capacity results, this is indicated from the graph.

The results of research from Pinzon [10] conducted on medical students aged 18-22 years showed that the vital capacity of a person's lungs can be affected by his body mass index. Individuals with the normal-excess body have a lower percentage of vital lung capacity than the normal-thin individuals [10]. The results of a study by Stephanie (2011) conducted on students of the Unjani Faculty of Medicine stated that there was a relationship between body weight, height, and body surface area with lung vital capacity [11].

A person who is obese may change the characteristics of the respiratory mechanical system, namely the presence of adipose tissue around the ribs, abdomen, and visceral cavities that fill the chest wall resulting in increased intra-abdominal pressure, decreasing end-expiratory lung volume, decreased chest wall compliance, breathing work. increase which is basically due to a decrease in expiratory residual volume, vital capacity, and total lung capacity [5,6]. The results of this study are in accordance with various theories and previous studies, namely the existence of a relationship between obesity and vital lung capacity.

\section{CONCLUSION}

From this research could be concluded that there was a relationship between Lung vital capacity with obesity in students of the Faculty of Medicine of the University of Jenderal Achmad Yani $(\mathrm{p}<0.05)$. The higher body mass index values cause vital lung capacity decreased.

Further study is needed to compare the vital capacities of the lungs in different sexes.

\section{REFERENCES}

[1] World Health Organization, "Overweight and obesity," [online] Retrieved from http://www.searo.who.int/entity/noncommunicable_diseases/media/non_ communicable_diseases_obesity_fs.pdf?ua $=1$.

[2] Dinas Kesehatan Jawa Barat, Profil kesehatan 2015. Dinkes Jabar. Jawa Barat 2015 .

[3] Riset Kesehatan Dasar, badan penelitian dan pengembangan. Jakarta: Depkes RI, 2013.

[4] C. Zammit, H. Liddicoat, I. Moonsie, and H. Makker, "Obesity and respiratory diseases," International Journal of General Medicine, vol. 3, pp. 335-43, 2010 .

[5] C.M. Salome, G.G. King, and N. Berend, "Physiology of obesity and effect on lung function," American Physiology Society, vol. 108, pp. 206-11, 2010

[6] A. Pedoto, "Lung physiology and obesity: anesthetic implications for thoracic procedure," Hindiawi Publishing Corporation, pp. 1-7, 2012.

[7] M. Mukhlis and A. Bakhtiar, "Obstructive Sleep Apneu (OSA), Obesity Hypoventilation Syndrom (OHS) dan gagal napas," Departemen Pulmonologi dan Ilmu Kedokteran Fakultas Kedokteran Universitas Airlangga/RSUD Dr. Soetomo, vol. 1, pp. 94-101, 2015.

[8] F. Harahap and E. Aryastuti, "Uji fungsi paru," CDK, vol. 39, pp. 30507, 2012.

[9] W. Jannah, E. Bebasari, and Y. Ernalia, "Profil status gizi mahasiswa fakultas kedokteran universitas Riau angkatan 2012 dan 2013 berdasarkan indeks massa tubuh, waist hip ratio dan lingkar pinggang," JOM, vol. 1, pp. 1-7, 2015.

[10] R. Pinzon, "Hubungan indeks massa tubuh dengan kapasitas vital paruparu golongan usia muda," Buletin Peneliti Kesehatan, vol. 26, pp. 1518, 1999.

[11] Y. Stephanie. Hubungan antara berat badan, tinggi badan, dan luas permukaan tubuh dengan kapasitas vital paru mahasiswa fakultas kedoktern Unjani angkatan 2008 dan 2009. Repository FK Unjani 2011 , p. 61.

[12] S. Sugondo, "Obesitas," Ilmu Penyakit Dalam, vol. 2, pp. 2565-67, 2015.

[13] Y.S. Hasibuan, Hubungan obesitas dengan kapasitas vital paru mahasiswa program studi pendidikan dokter universitas syuah kuala banda aceh darussalam: Universitas Syiah Kuala, 2015.

[14] Y.A. Lubis, Pengaruh obesitas terhadap kejadian hipertensi kejadian hipertensi: Universitas Syiah Kuala, 2013. 